\title{
The Antibiofilm efficacy of nitric oxide on soft contact lenses
}

\author{
Dong Ju Kim ${ }^{\dagger}$, Joo-Hee Park ${ }^{\dagger}$, Marth Kim and Choul Yong Park ${ }^{*}$ (D)
}

\begin{abstract}
Background: To investigate the antibiofilm efficacy of nitric oxide (NO) on soft contact lenses.

Methods: Nitrite (NO precursor) release from various concentrations (0-1000 $\mu \mathrm{M})$ of sodium nitrite $\left(\mathrm{NaNO}_{2}, \mathrm{NO}\right.$ donor) was measured by Griess Assay. Cell viability assay was performed using human corneal epithelial cell under various concentration (0-1000 $\mu \mathrm{M}$ ) of $\mathrm{NaNO}_{2}$. Biofilm formation on soft contact lenses was achieved by adding Staphylococcus aureus or Pseudomonas aeruginosa to the culture media. Various concentrations of $\mathrm{NaNO}_{2}(0-1000 \mu \mathrm{M})$ were added to the culture media, each containing soft contact lens. After incubation in $\mathrm{NaNO}_{2}$ containing culture media for 1, 3, or 7 days, each contact lens was transferred to a fresh, bacteria-free media without $\mathrm{NaNO}_{2}$. The bacteria in the biofilm were dispersed in the culture media for planktonic growth. After reculturing the lenses in the fresh media for $24 \mathrm{~h}$, optical density (OD) of media was measured at $600 \mathrm{~nm}$ and colony forming unit (CFU) was counted by spreading media on tryptic soy agar plate for additional $18 \mathrm{~h}$.
\end{abstract}

Results: Nitrite release from $\mathrm{NaNO}_{2}$ showed dose-dependent suppressive effect on biofilm formation. Most nitrite release from $\mathrm{NaNO}_{2}$ tended to occur within $30 \mathrm{~min}$. The viability of human corneal epithelial cells was well maintained at tested $\mathrm{NaNO}_{2}$ concentrations. The bacterial CFU and OD showed dose-dependent decrease in the $\mathrm{NaNO}_{2}$ treated samples on days 1, 3 and 7 for both Staphylococcus aureus and Pseudomonas aeruginosa.

Conclusions: NO successfully inhibited the biofilm formation by Staphylococcus aureus or Pseudomonas aeruginosa on soft contact lenses in dose-dependent manner.

Keywords: Nitrite, Nitric oxide, Biofilm, Contact lens, Bacterial keratitis, Cornea

\section{Background}

Bacteria accounts for most cases of the infectious keratitis. If not properly treated, bacterial keratitis can cause sight-threatening complications, such as corneal opacity or perforation [1-3]. Contact lens wearing significantly increases the risk of bacterial keratitis and it was reported that about 3.5 to 20 soft contact lens wearers developed bacterial keratitis every year [4]. Corneal hypoxia and epithelial damage induced by wearing contact lenses enhances the bacterial adhesion and invasion [4]. Normal host defense mechanism against pathogen, such as tear and blinking can also be significantly interfered by wearing contact lenses [5]. Furthermore, mucins and proteins can attach on the surface of contact lens and promote the pathogen adhesion. The adhesion of

\footnotetext{
* Correspondence: oph0112@gmail.com

${ }^{\dagger}$ Equal contributors

Department of Ophthalmology, Dongguk University, Ilsan Hospital, 814,

Siksadong, Ilsan-dong-gu, Goyang, Gyunggido 410-773, South Korea
}

specific bacteria to contact lens can form a biofilm [5]. A biofilm is a complex of microbial communities enclosed in an exopolysaccharide matrix adhered to the surface of prosthetics or living organism [6, 7]. Biofilms enable bacteria to survive in unfavorable environments by reducing their metabolic needs, inhibiting the penetration of antimicrobial agents and increasing their inherent resistance to antimicrobial agents [8]. In addition, biofilms formed on contact lenses can play a critical role in developing bacterial keratitis as a depot for continuous bacterial release [8-10].

Nitric oxide (NO) is a one of well-known antibacterial mechanisms of mammalian host [11]. As a small molecular gas, NO can diffuse freely across the cellular membrane [12]. When generated locally with micromolar concentration, $\mathrm{NO}$ acts as a cytotoxic antimicrobial agent [11]. In addition, previous studies have shown that NO could act as a key mediator for biofilm 
dispersal $[13,14]$. It was reported that low concentrations of NO induced biofilms dispersal while high concentrations of NO directly killed pathogens [15]. It is known that high concentrations of NO have a broad antibiotic spectrum that can act on both gram positive and negative or both mono-species and multi-species biofilms [16-20].

Bacteria such as Staphylococcus aureus and Pseudomonas aeruginosa contains nitrite reductase which converts nitrite $\left(\mathrm{NO}_{2}^{-}\right)$to NO. The gene encoding nitrite reductase is known as nas DE or nirBD in Staphylococcus aureus and nirS in Pseudomonas aeruginosa [21, 22].

Although the evidences of anti-biofilm effect of NO are growing, the study investigating the effect of $\mathrm{NO}$ on soft contact lens-associated biofilms is hard to find. Considering the clinical importance of contact lens associated biofilms and resulting bacterial keratitis, the role of NO on soft contact lens-associated biofilm is an interesting research topic.

In the current study, we used sodium nitrite $\left(\mathrm{NaNO}_{2}\right)$ as a NO donor and investigated the inhibitory effects of $\mathrm{NO}$ on soft contact lens-associated biofilms by Staphylococcus aureus and Pseudomonas aeruginosa, which are two of most common strains of infectious keratitis [23, 24].

\section{Methods}

\section{Griess assay for nitrite release}

The nitrite release from $\mathrm{NaNO}_{2}$ (Sigma_Aldrich St. Louis, MO, USA) was measured using Griess Reagent System Kit (catalog number: G2930; Promega Corp., Madison, WI, USA). The Griess Reagent System is based on the chemical reaction, which uses sulfanilamide and $\mathrm{N}$-1-napthylethylenediamine dihydrochloride (NED) under acidic conditions. This system detects nitrite in liquid matrices. A nitrite standard reference curve was obtained for the accurate quantitation of nitrite levels in experimental samples. A sulfanilamide solution $(50 \mu \mathrm{L})$ was dispensed to all experimental samples, which were then incubated for $10 \mathrm{~min}$ at room temperature while protected from light. After the incubation, $50 \mu \mathrm{L}$ of the NED solution was added to all samples, which were then further incubated at room temperature for $10 \mathrm{~min}$ with light protection. Finally, the measurement of absorbance at $540 \mathrm{~nm}$ was performed with a plate reader. The nitrite release from $\mathrm{NaNO}_{2}$ at different concentrations $(0,0.1$, $1,10,100,1000 \mu \mathrm{M})$ was tested for $30 \mathrm{~m}, 6 \mathrm{~h}$ and $24 \mathrm{~h}$.

\section{Cell viability assay}

Cell viability assay was performed using CCK-8 reagent (Dojindo Molecular Technologies, Inc. Kumamoto, Japan) according to the manufacturer's protocol. Briefly, human corneal epithelial cells (HCECs) were cultured at $4 \times 10^{3}$ cells/ well in a 96-well plate and incubated for $24 \mathrm{~h}$. Following the adherence of cells, $\mathrm{NaNO}_{2}$ was dose dependently treated to cells for $3 \mathrm{~h}, 6 \mathrm{~h}, 24 \mathrm{~h}$, and $48 \mathrm{~h}$ at concentrations of $0,0.1,1,10,100$ and $1000 \mu \mathrm{M}$. After the appropriate incubation, $10 \%(\mathrm{v} / \mathrm{v})$ of CCK- 8 solution was added to the culture media and the absorbance at $450 \mathrm{~nm}$ was measured after $2 \mathrm{~h}$ of incubating the HCECs with the reagent.

\section{Bacterial culture}

Staphylococcus aureus (S. aureus; ATCC 25923) and Pseudomonas aeruginosa (P. aeruginosa; ATCC 10145) were purchased from American type culture collection (ATCC; Manassas, VA, USA). Both bacteria were cultured in a tryptic soy broth (soybean-casein digest media; Becton Dickinson and Company; BD, Franklin Lakes, NJ, USA) and were maintained at $37^{\circ} \mathrm{C}$ incubator under aerobic condition with soft contact lenses (Hioxifilcon-A, Interojo, Gyeonggi-do, Pyeongtaek, South Korea).

\section{Treatment of $\mathrm{NaNO}_{2}$ in bacterial culture}

Soft contact lenses and bacteria (S. aureus or P. aeruginosa) were cultured together with the treatment of various concentrations $(0,0.1,1,10,100$ and $1000 \mu \mathrm{M})$ of $\mathrm{NaNO}_{2}$. The bacteria were cultured $24 \mathrm{~h}$ in 24-well plate before the treatment of $\mathrm{NaNO}_{2}$ and was used at $\geq 0.55$ (optical density $\left.(\mathrm{OD})_{600}\right)$. A stock solution of $1 \mathrm{M}-\mathrm{NaNO}_{2}$ were serially diluted and gently mixed with culture media to reach the final desired concentrations of $\mathrm{NaNO}_{2}$ and the media were maintained at $37{ }^{\circ} \mathrm{C}$ in an incubator under aerobic condition. $\mathrm{NaNO}_{2}$ was mixed to the culture media once a day. On first, third, and seventh days, cultured soft contact lenses were removed from the plate and gently washed in phosphate buffered saline(PBS) for three times, and then transferred to new 24-well plate containing fresh media for reculturing for additional $24 \mathrm{~h}$. After $24 \mathrm{~h}$ of reculturing, the optical density (OD) of bacterial solutions was measured at wavelength of $600 \mathrm{~nm}$ using a spectrophotometer (SpectraMax plus 384 microplate reader, Molecular Devices, Sunnyvale, Ca, USA) (Fig. 1).

\section{Colony forming unit (CFU) assay}

The media $24 \mathrm{~h}$ after the reculturing of the contact lenses were diluted and spread on a tryptic soy agar (Becton Dickinson and Company, Franklin Lakes, NJ, USA) plate, and maintained at $37{ }^{\circ} \mathrm{C}$ in an incubator under aerobic conditions for another $18 \mathrm{~h}$. After the culturing, the bacterial colonies were counted (Fig. 1).

\section{Statistical analysis}

The experiments were conducted three times in total, and the results were derived from all three sets of experimental data. IBM SPSS ver. 20.0 (IBM Corp., Armonk, NY, USA) was used for all the statistical analyses. The statistically significance of CFU, OD, cell viability was determined using one-way analysis of 


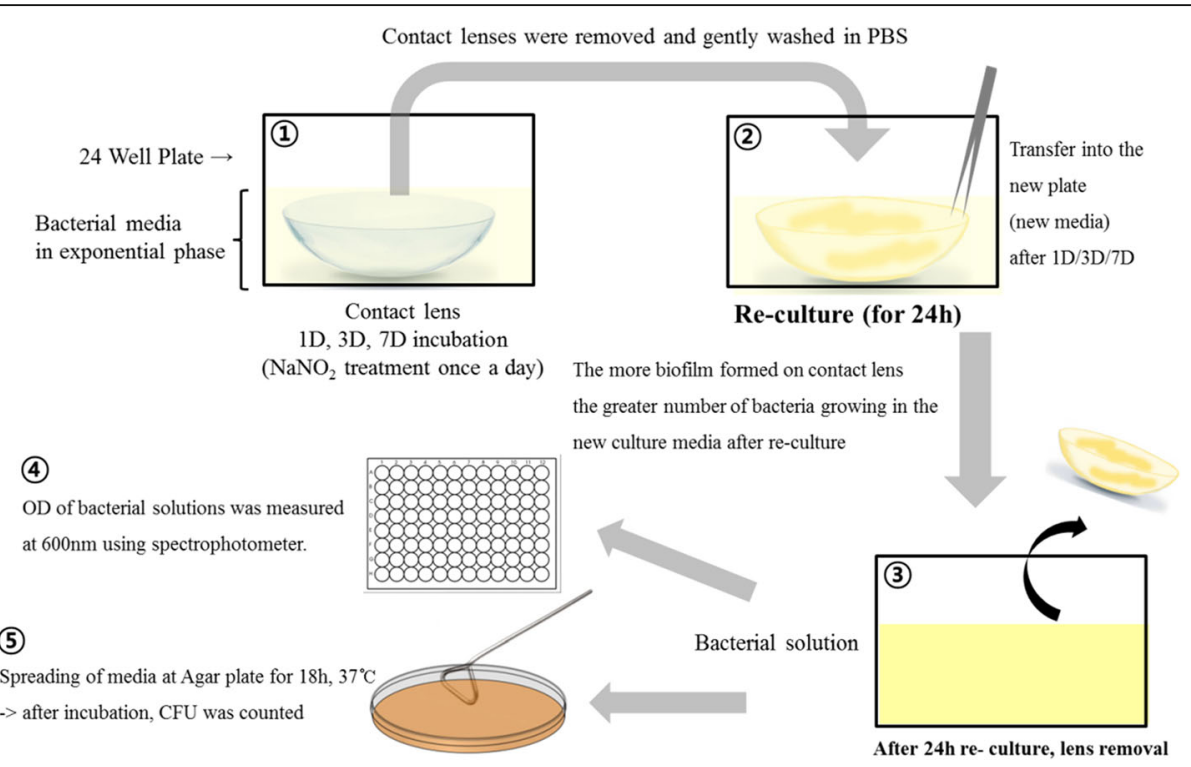

Fig. 1 Schematic illustration showing the reculturing methods used to evaluate antibiofilm effect of nitric oxide. 1) Soft contact lens was incubated with bacteria for 1-7 days. 2) To analyse the biofilm attached to each contact lens, only the contact lens was harvested and transferred to fresh culture media for additional 24-h culture. 3, 4 \& 5 ) After $24 \mathrm{~h}$ of re-culture, the bacterial burden dispersed in the culture media was analysed by optical density measurement and colony forming unit counting

variance (ANOVA) followed by the Tukey honestly significant difference (HSD) test. $P$ values less than 0.05 were considered statistically significant.

\section{Results}

\section{Griess assay for measuring released nitrite}

Most nitrite release from $\mathrm{NaNO}_{2}$ occurred within $30 \mathrm{~min}$, as shown in Fig. 2. Nitrite release decreased significantly as time elapsed, reaching approximately $10 \%$ of the initial nitrite release when measured after $6 \mathrm{~h}$.

\section{Cell viability}

In general, no detrimental effect of $\mathrm{NaNO}_{2}$ on cellular viability was observed (Fig. 3). A mild increase in cellular viability was observed with $0.1-1000 \mu \mathrm{M}$ of $\mathrm{NaNO}_{2}$ after 6,12 , and $24 \mathrm{~h}$ of incubation.

\section{Nitrite effect of contact lens biofilm}

$\mathrm{NaNO}_{2}$ decreased the biofilm formation of both $S$. aureus and $P$. aeruginosa in a dose-dependent manner (Figs. 4 and 5). Reculturing contact lenses with biofilm is a kind of indirect method for quantification of biofilm. Larger amounts of biofilm contain a heavier burden of pathogens. After change of the environment (from an $\mathrm{NO}$ positive to an NO negative culture condition), pathogens can release from the biofilm to culture media for planktonic growth. Exponential growth of pathogen can change the OD of the culture media, making the media more turbid. OD measured in this study therefore represent the pathogen burden contained in biofilm.

The OD of recultured media decreased with the addition of $\mathrm{NaNO}_{2}$. Even a low concentration $(0.1 \mu \mathrm{M})$ of $\mathrm{NaNO}_{2}$ decreased the biofilm by almost $50 \%$

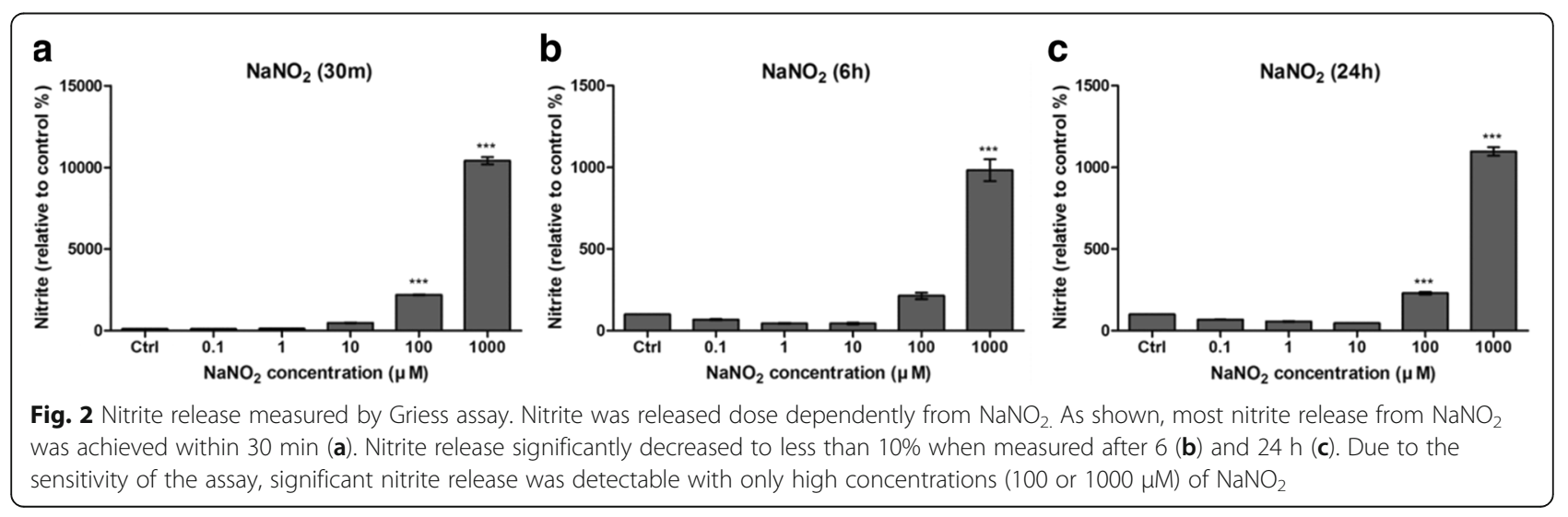



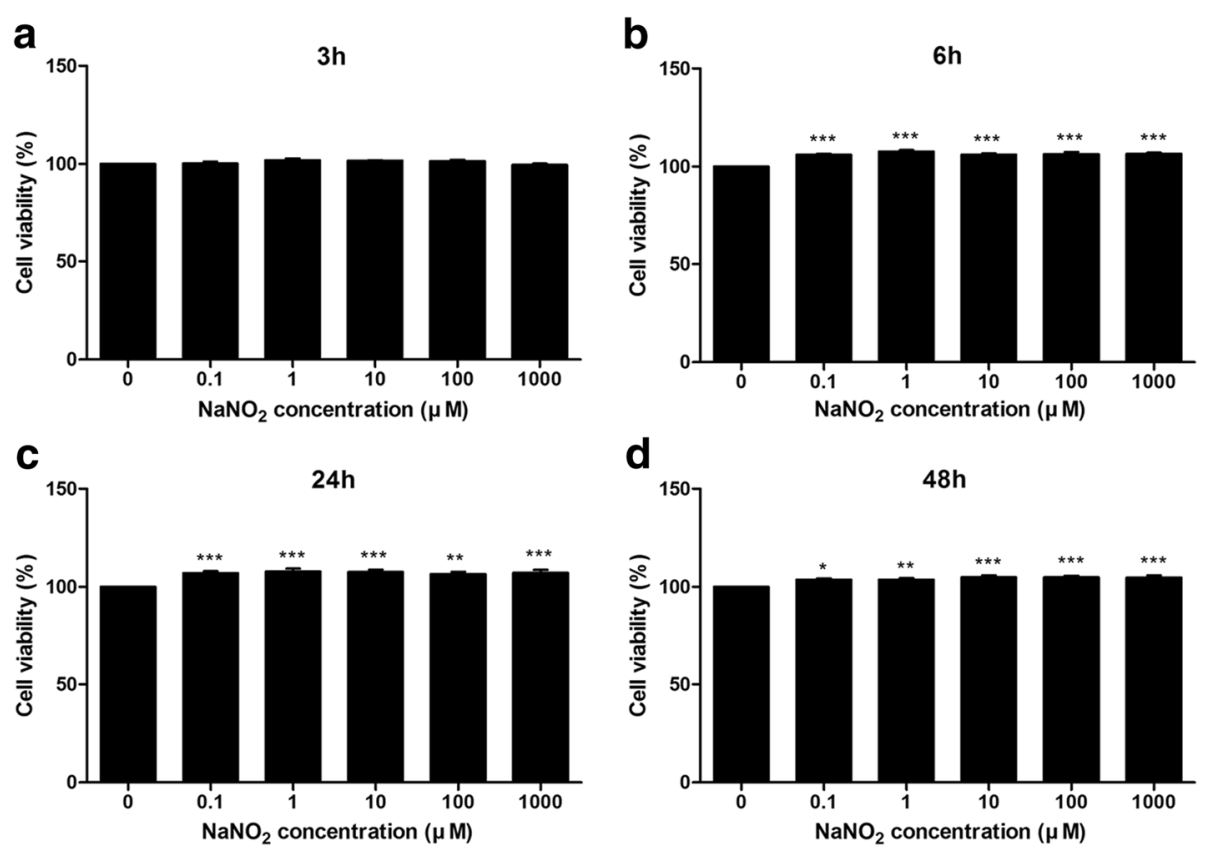

Fig. 3 Human corneal epithelial cell viability assay. Human corneal epithelial cell viability was measured using CCK-8 kit after 3 (a), 6 (b), 24 (c) and $48 \mathrm{~h}$ (d) of incubation with various concentrations $(0.1-1000 \mu \mathrm{M})$ of $\mathrm{NaNO}_{2}$. The graphs showed a mild increase in cell viability with $\mathrm{NaNO}_{2}$ addition at 6, 24 and $48 \mathrm{~h}$. No detrimental effect of $\mathrm{NaNO}_{2}$ on cell viability was observed at the tested concentrations. Triplicates of each treatment group were used in each independent experiment. Values are the mean \pm standard error of means from three independent experiments. $\left({ }^{*} p<0.05,{ }^{* *} p<0.01,{ }^{* * *} p<0.001\right)$
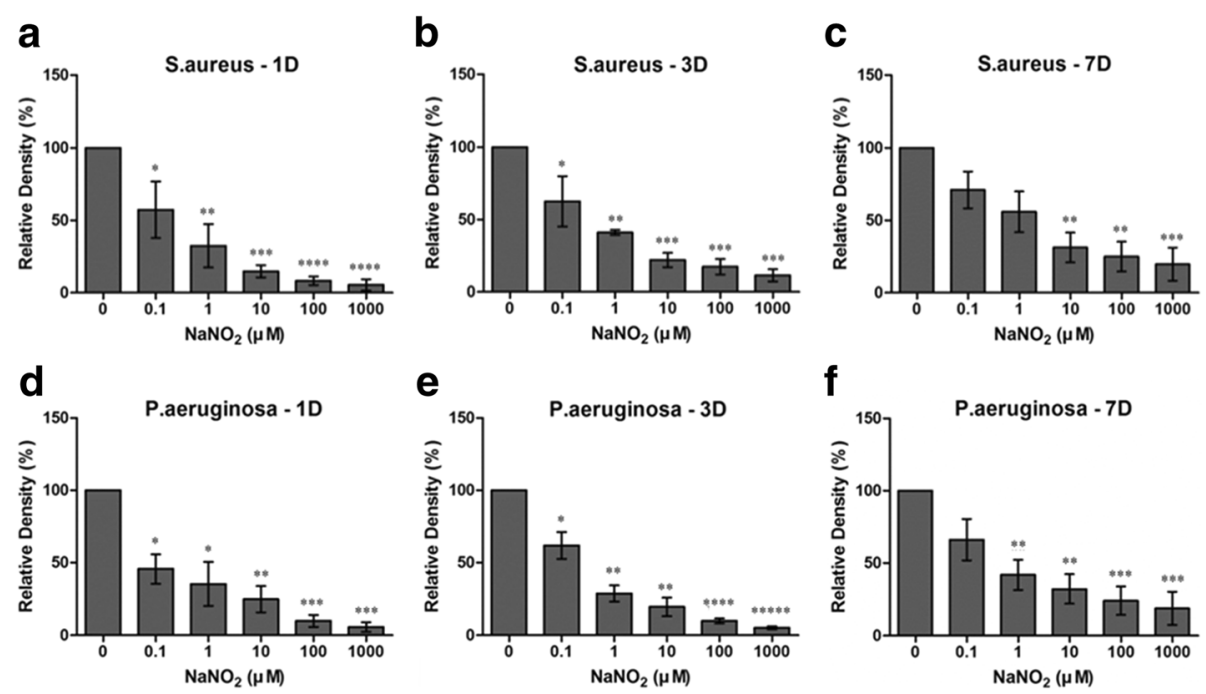

Fig. 4 Nitric oxide's effect on contact lens associated biofilm analyzed by optical density analysis. Optical density (OD) of samples was converted to relative density (\%) (the OD of the sample divided by OD of the negative control) and was shown in bar graphs. a-c OD comparison in samples with Staphylococcus aureus. The OD was lower than the negative control at all concentrations of $\mathrm{NaNO}_{2}$ at days 1 and 3 . The effect of $\mathrm{NaNO}_{2}$ on biofilm formation was dose dependent. At day 7, low concentrations (0.1 and $1 \mu \mathrm{M}$ ) of $\mathrm{NaNO}_{2}$ decreased the biofilm but failed to reach statistical significance. Higher concentrations (10-1000 $\mu \mathrm{M})$ of $\mathrm{NaNO}_{2}$ significantly decreased the biofilm formation even at day 7 . $\mathbf{d}-\mathbf{f} \mathrm{OD}$ comparison in samples with Pseudomonas aeruginosa. The OD was lower than the negative control at all concentrations of $\mathrm{NaNO}_{2}$ at days 1 and 3. The effect of $\mathrm{NaNO}_{2}$ on biofilm formation was dose dependent. At day 7, low concentrations $(0.1 \mu \mathrm{M})$ of $\mathrm{NaNO}_{2}$ decreased the biofilm but failed to reach statistical significance. Higher concentrations (1-1000 $\mu \mathrm{M})$ of $\mathrm{NaNO}_{2}$ significantly decreased the biofilm formation even at day 7 . Statistical significance was determined using one-way analysis of variance (ANOVA) followed by the Tukey HSD test. *Statistically significantly higher than control group, **Statistically significantly higher than $0.1 \mu \mathrm{M}$ group. ${ }^{* *}$ Statistically significantly higher than $1 \mu \mathrm{M}$ group, ${ }^{* * *}$ Statistically significantly higher than $10 \mu \mathrm{M}$ group, ${ }^{* * * *}$ Statistically significantly higher than $100 \mu \mathrm{M}$ group 


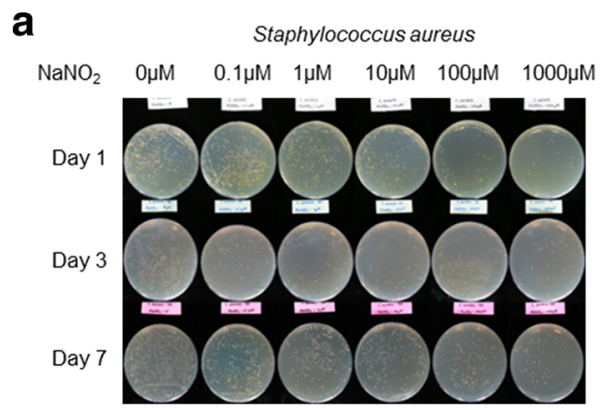

C

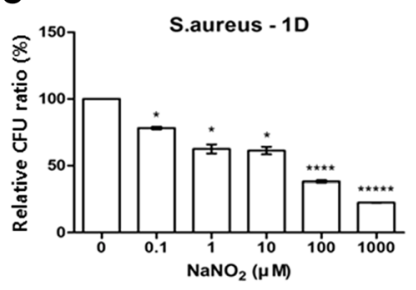

f

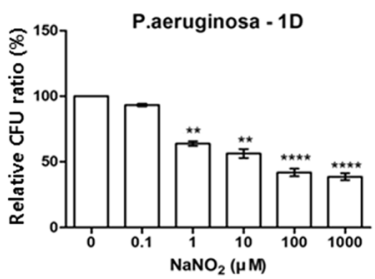

d

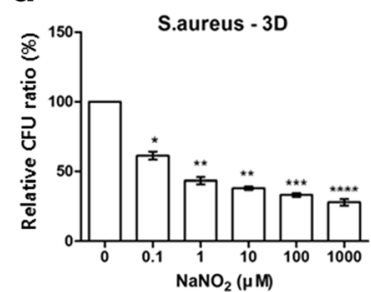

g

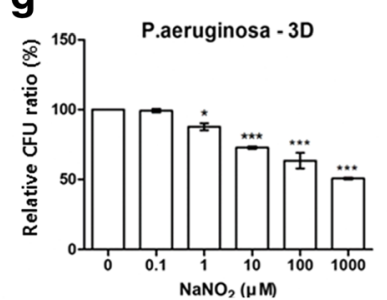

Pseudomonas aeruginosa

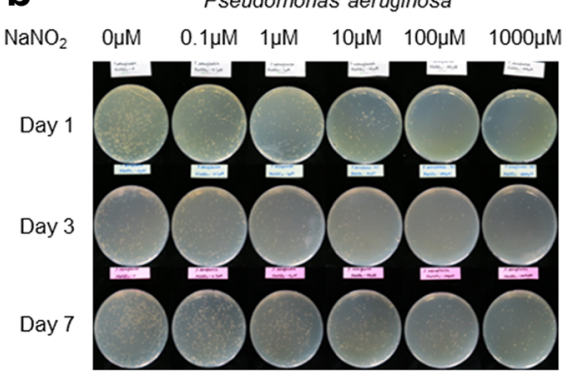

e

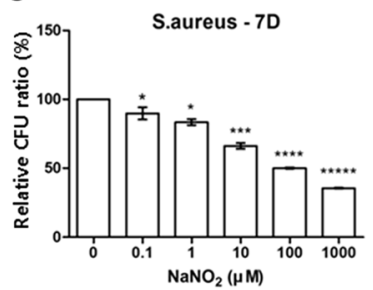

h

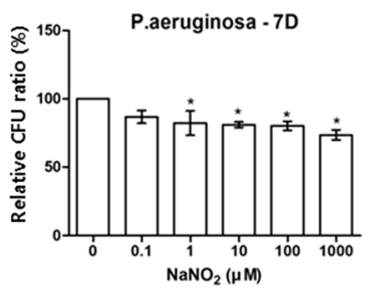

Fig. 5 Nitric oxide's effect on contact lens-associated biofilm analyzed by colony forming unit counting analysis. a and $\mathbf{b}$ Representative pictures of agar plates showing the colonies after $24 \mathrm{~h}$ of reculturing. Colony forming unit (CFU) count decreased with increasing concentrations of $\mathrm{NaNO}_{2}$ in both $\mathrm{S}$. aureus and $P$. aeruginosa. The number of scattered colonies decreased with increasing concentrations of $\mathrm{NaNO}_{2}$. c- $\mathbf{h}$ The $\mathrm{CFU}$ count of the samples was converted to the ratio (\%) (the CFU count of the sample divided by CFU count of the negative control) and was shown in bar graph. The CFU count of both $S$. aureus and $P$. aeruginosa shows dos-dependent decrease with increasing concentration of $\mathrm{NaNO}_{2}$. The suppressing effect of $\mathrm{NaNO}_{2}$ decreased at day 7 in biofilm formed by $P$. aeruginosa. Statistical significance was determined using one-way analysis of variance (ANOVA) followed by the Tukey HSD test. *Statistically significantly higher than control group, **Statistically significantly higher than $0.1 \mu \mathrm{M}$ group.** Statistically significantly higher than $1 \mu \mathrm{M}$ group, ${ }^{* * *}$ Statistically significantly higher than $10 \mu \mathrm{M}$ group, ${ }^{* * * * S t a t i s t i c a l l y}$ significantly higher than $100 \mu \mathrm{M}$ group

compared with the control. A high concentration $(1 \mathrm{mM})$ of $\mathrm{NaNO}_{2}$ further decreased the biofilm formation to less than $10 \%$ of the control even on the first day (Fig. 4). Similar findings were repeated with CFU analysis. However, the effect of $\mathrm{NaNO}_{2}$ measured by $\mathrm{CFU}$ analysis seemed to be blunted compared to OD analysis at day 7 , especially with $P$. aeruginosa (Fig. 5).

\section{Discussion}

In this study, we found that NO showed a dose-dependent suppression of the biofilm formed on soft contact lenses by $S$. aureus and $P$. aeruginosa. In addition, the tested concentrations of $\mathrm{NaNO}_{2}$ showed no significant toxicity on cultured human corneal epithelial cells.

Biofilm formation on the surface of the medical device is closely related to various infectious diseases because it increases continuous pathogen dispersion $[7,8,25]$. It is known that biofilm forms commonly on contact lenses and is one of the major risk factors for infectious keratitis [1, 26-28]. The characteristics of the contact lenses, such as hydrophobicity or surface irregularity, can also affect bacterial attachment and subsequent biofilm formation [29]. Furthermore, biofilm formation on the anterior surface of contact lens can be somewhat prevented by natural host defense mechanisms such as blinking movement and antimicrobial components within tears [30]. However, the posterior surface of the contact lens touches the cornea and this contact interferes natural defense mechanisms [31]. Therefore, biofilm is found commonly on the posterior surface of contact lens [9]. Bacteria within biofilm are more resistant to antibiotics and host defense mechanisms compared to free planktonic form of bacteria [6,32].

Previous studies found that $\mathrm{NO}$ is a key mediator of biofilm dispersal [13, 15, 16, 33, 34]. Biofilm dispersal needs some molecular triggers which induce a change 
from biofilm to dispersal phenotype. One of these triggers is a low concentration of $\mathrm{NO}$ and another is a decrease of intracellular c-di-GMP [17, 35, 36]. Low concentrations of NO induce biofilm dispersal via signal cascades involving both increase of phosphodiesterase activity and decrease of intracellular c-di-GMP $[14,15]$. In addition, planktonic bacteria exposed to low concentrations of NO become even more susceptible to other antibiotics [37, 38].

It is known that high concentrations of NO are broadspectrum bactericidal agents that can kill both gram positive and negative bacteria [38-40]. However, NO can also be toxic to host cells at high concentrations. High concentrations of NO can be converted to reactive nitrogen species such as peroxynitrite and reactive nitrogen species can cause cytotoxic effects not only on pathogens but also on host cells.

NO is an unstable free radical gas and has limited solubility in water [12]. This makes it difficult to introduce pure gaseous NO into the culture media. Therefore, various chemical agents that release $\mathrm{NO}$, such as sodium nitroprusside, sodium nitrate $\left(\mathrm{NaNO}_{3}\right)$ or sodium nitrite $\left(\mathrm{NaNO}_{2}\right)$, have been widely used as $\mathrm{NO}$ donor for biological experiment evaluating $\mathrm{NO}$ effect $[17,41]$. In our study, $\mathrm{NaNO}_{2}$ was used as a $\mathrm{NO}$ donor. $\mathrm{NaNO}_{2}$ yields nitrite and nitrite can be converted to $\mathrm{NO}$ by nitrite reductase. In the previous report, exogenous supply of $\mathrm{NaNO}_{2}$ successfully decreased the biofilm formation on the culture plate by $S$. aureus and $P$. aeruginosa [42].

We tested the safety of $\mathrm{NaNO}_{2}$ of concentrations $(0.1,1,10,100$ and $1000 \mu \mathrm{M})$ using HCECs. The viability of HCECs was not interrupted by $\mathrm{NaNO}_{2}$ up to $48 \mathrm{~h}$ at all tested concentrations. In addition, the contact lens biofilm formed by $S$. aureus and $P$. aeruginosa successfully decreased following addition of $\mathrm{NaNO}_{2}$. Our results are consistent with previous studies that showed the suppressive effect of $\mathrm{NO}$ on biofilm and bacteria on other medical devices [13, 33, 34].

In this study, CFU count tended to increase over a week even with the presence of NO especially in P. aeruginosa. We hypothesize that biofilm formation was inhibited only during the short action period of NO and the residual bacteria then proliferated again. In our study, $\mathrm{NaNO}_{2}$ was applied once a day to avoid significant change of osmotic pressure of culture media. As a relatively unstable gas, NO has a short half- life [12]. As shown in Fig. 2, the most robust action of $\mathrm{NO}$ was expected within $30 \mathrm{~min}$ every day in our experimental setting. Therefore, the increase in the CFU count at day 7 might be the cumulative effect of bacterial regrowth during NO-free period of each day. Another possible explanation might be the limited diffusion of $\mathrm{NO}$ through the already established biofilm formation by
P. aeruginosa at day 7. As previously known, biofilm can protect microorganisms by providing mechanical diffusion barrier to antimicrobial agent [8].

In previous reports, the optimal $\mathrm{NO}$ concentration for biofilm suppression was different in two bacteria studied. $P$. aeruginosa was more susceptible to biofilm dispersal at lower concentrations $(0.025 \sim 2500 \mathrm{nM})$ of NO. $[13,33]$ On the other hand, relatively high concentrations $(124 \sim 1000 \mu \mathrm{M})$ of NO was necessary to inhibit biofilm formation by $S$. aureus [43]. However, our result revealed that both bacteria were susceptible to biofilm dispersal at similar $\mathrm{NaNO}_{2}$ concentration range (0.1 to $1000 \mu \mathrm{M})$. We believe that the difference in the strains and experimental settings (biofilm formation on soft contact lens and different NO donor) may explain the discrepancies between studies.

Although it is one of the first pioneering study to evaluate NO effect on contact lens associated biofilm, this study has several limitations. The first, the interaction of bacteria and host immune system and its modulation by $\mathrm{NO}$ was not elucidated in our in vitro study. Secondly, we used the indirect method for the quantification of biofilm, the re-culturing from biofilm, instead of direct quantification of biofilm. We initially tried direct staining and biofilm quantification on contact lenses using crystal violet after complete drying of contact lens. However, there were several drawbacks that made us abandon the direct staining method. We found that the contact lens itself was heavily stained by crystal violet. In addition, a significant amount of biofilm formed on contact lens was not fixed and continuously dropped out during washing, drying and staining procedure. In addition, thermal fixation could not be applied because it would burn the contact lens. Therefore, we chose the indirect quantification method and assumed that only the biofilm attached to the contact lens was the source of bacterial growth in the recultured media. The similar methods were reported to quantify biofilm development on intraocular lens surface previously $[44,45]$. In our study, both OD measurement and CFU count were adopted to increase the accuracy of biofilm quantification. Thirdly, $\mathrm{NaNO}_{2}$ was treated only once a day because osmotic change from the additional sodium in $\mathrm{NaNO}_{2}$ can affect bacterial growth. NO release from $\mathrm{NaNO}_{2}$ is expected to be quite concentrated within $30 \mathrm{~min}$ of $\mathrm{NaNO}_{2}$ 's application to the culture media, so a more stable and continuous NO donor would be optimal for investigating dose-dependent effect of NO. Furthermore, the exact quantification of NO production from nitrite was not measured in this study. The difference between experimental and physiological conditions should be also considered for interpretation of our results. The dynamic tear clearance and lens movement were absent in our experimental settings and these 
two factors might change the biofilm kinetics in human ocular surface [46]. Finally, the effect of NO on multispecies biofilms was not investigated even though multispecies-associated keratitis is common with contact lens wear [27].

The clinical significance of our results is the potential use of $\mathrm{NO}$ as an active disinfectant in contact lens care solution. $\mathrm{NO}$ donors such as $\mathrm{NaNO}_{2}$ or sodium nitroprusside are already used as intravenous medications for the treatment of cyanide poisoning $\left(\mathrm{NaNO}_{2}\right)$ and heart diseases (sodium nitroprusside) [47, 48]. Therefore, if ophthalmic topical safety is ensured through clinical trials, a tablet form of these chemicals can be mixed into daily dispense of contact lens care solution to eradicate bacterial biofilm.

\section{Conclusion}

In conclusion, we confirmed that NO can suppress biofilm formation on soft contact lens in a dose dependent manner. Our findings suggest that NO can be developed as a new therapeutic strategy to reduce biofilmassociated contact lens infection with minimal toxicity to corneal epithelium.

\section{Abbreviations}

CFU: Colony forming unit; NO: Nitric oxide; OD: Optical density

\section{Acknowledgements}

Not applicable

\section{Funding}

Publication of this article was supported in by a grant of the Korea Health Technology R\&D Project through the Korea Health Industry Development Institute (KHIDI), funded by the Ministry of Health \& Welfare, Republic of Korea (Grant number: HI-15C1653) and Basic Science Research Program through the National Research Foundation of Korea (NRF) funded by the Ministry of Education (Grant number: 2016R1D1A1B03931724).

\section{Availability of data and materials}

All data are available upon request to the corresponding author at oph0112@gmail.com

\section{Authors' contributions}

DJK, JHP, MK and CYP were responsible for the conception and design of the study. DJK and JHP acquired the data. JHP, CYP and MK analyzed and interpreted the data. DJK and CYP wrote the draft. MK and CYP revised the manuscript critically. All authors have read and approved the final manuscript.

\section{Ethics approval and consent to participate}

Not applicable

\section{Consent for publication}

Not applicable

\section{Competing interests}

The authors declare that they have no competing interests.

\section{Publisher's Note}

Springer Nature remains neutral with regard to jurisdictional claims in published maps and institutional affiliations.
Received: 26 July 2017 Accepted: 15 November 2017

Published online: 21 November 2017

\section{References}

1. Dart JK, Stapleton F, Minassian D. Contact lenses and other risk factors in microbial keratitis. Lancet. 1991;338(8768):650-3.

2. Tabbara KF, El-Sheikh HF, Aabed B. Extended wear contact lens related bacterial keratitis. Br J Ophthalmol. 2000;84(3):327-8.

3. Morgan PB, Efron N, Hill EA, Raynor MK, Whiting MA, Tullo AB. Incidence of keratitis of varying severity among contact lens wearers. Br J Ophthalmol. 2005:89(4):430-6.

4. Robertson DM. The effects of silicone hydrogel lens wear on the corneal epithelium and risk for microbial keratitis. Eye Contact Lens. 2013;39(1):67-72.

5. Stern GA. Contact lens associated bacterial keratitis: past, present, and future. CLAO J. 1998:24(1):52-6.

6. McLaughlin-Borlace L, Stapleton F, Matheson M, Dart JK. Bacterial biofilm on contact lenses and lens storage cases in wearers with microbial keratitis. J Appl Microbiol. 1998;84(5):827-38.

7. Percival SL, Suleman L, Vuotto C, Donelli G. Healthcare-associated infections, medical devices and biofilms: risk, tolerance and control. J Med Microbiol. 2015;64(Pt 4):323-34.

8. Veerachamy S, Yarlagadda T, Manivasagam G, Yarlagadda PK. Bacterial adherence and biofilm formation on medical implants: a review. Proc Inst Mech Eng H J Eng Med. 2014;228(10):1083-99.

9. Dutta D, Cole N, Willcox M. Factors influencing bacterial adhesion to contact lenses. Mol Vis. 2012;18:14-21.

10. Cheng KH, Leung SL, Hoekman HW, Beekhuis WH, Mulder PG, Geerards AJ, Kijlstra A. Incidence of contact-lens-associated microbial keratitis and its related morbidity. Lancet. 1999;354(9174):181-5.

11. MacMicking J, Xie QW, Nathan C. Nitric oxide and macrophage function. Annu Rev Immunol. 1997;15:323-50.

12. Kelm M. Nitric oxide metabolism and breakdown. Biochim Biophys Acta. 1999:1411(2-3):273-89.

13. Barraud N, Hassett DJ, Hwang SH, Rice SA, Kjelleberg S, Webb JS. Involvement of nitric oxide in biofilm dispersal of Pseudomonas Aeruginosa. J Bacteriol. 2006;188(21):7344-53.

14. Kaplan JB. Biofilm dispersal: mechanisms, clinical implications, and potential therapeutic uses. J Dent Res. 2010;89(3):205-18.

15. Barraud N, Kelso MJ, Rice SA, Kjelleberg S. Nitric oxide: a key mediator of biofilm dispersal with applications in infectious diseases. Curr Pharm Des. 2015:21(1):31-42.

16. Arora DP, Hossain $S, X u Y$, Boon EM. Nitric oxide regulation of bacterial biofilms. Biochemistry. 2015:54(24):3717-28.

17. Barraud N, Storey MV, Moore ZP, Webb JS, Rice SA, Kjelleberg S. Nitric oxide-mediated dispersal in single- and multi-species biofilms of clinically and industrially relevant microorganisms. Microb Biotechnol. 2009:2(3):370-8.

18. Bispo PJ, Haas W, Gilmore MS. Biofilms in infections of the eye. Pathogens. 2015;4(1):111-36.

19. Rao M, Smith BC, Marletta MA. Nitric oxide mediates biofilm formation and Symbiosis in Silicibacter sp. strain TrichCH4B. MBio. 2015;6(3):e00206-15.

20. Wang Y, Ruby EG. The roles of NO in microbial symbioses. Cell Microbiol. 2011;13(4):518-26

21. Schlag S, Fuchs S, Nerz C, Gaupp R, Engelmann S, Liebeke M, Lalk M, Hecke M, Gotz F. Characterization of the oxygen-responsive NreABC regulon of Staphylococcus Aureus. J Bacteriol. 2008;190(23):7847-58.

22. Robinson JL, Jaslove JM, Murawski AM, Fazen $\mathrm{CH}$, Brynildsen MP. An integrated network analysis reveals that nitric oxide reductase prevents metabolic cycling of nitric oxide by Pseudomonas Aeruginosa. Metab Eng. 2017:41:67-81.

23. Passos RM, Cariello AJ, MC Y, Hofling-Lima AL. Microbial keratitis in the elderly: a 32-year review. Arq Bras Oftalmol. 2010;73(4):315-9.

24. Fleiszig SM, Evans DJ. The pathogenesis of bacterial keratitis: studies with Pseudomonas Aeruginosa. Clin Exp Optom. 2002;85(5):271-8.

25. Francolini I, Donelli G. Prevention and control of biofilm-based medicaldevice-related infections. FEMS Immunol Med Microbiol. 2010;59(3):227-38.

26. Hoddenbach JG, Boekhoorn SS, Wubbels R, Vreugdenhil W, Van Rooij J, Geerards AJ. Clinical presentation and morbidity of contact lens-associated microbial keratitis: a retrospective study. Graefes Arch Clin Exp Ophthalmol. 2014;252(2):299-306 
27. Bourcier T, Thomas F, Borderie V, Chaumeil C, Laroche L. Bacterial keratitis: predisposing factors, clinical and microbiological review of 300 cases. Br J Ophthalmol. 2003:87(7):834-8.

28. Keay L, Edwards K, Naduvilath T, Taylor HR, Snibson GR, Forde K, Stapleton F. Microbial keratitis predisposing factors and morbidity. Ophthalmology. 2006;113(1):109-16.

29. Bruinsma GM, van der Mei HC, Busscher HJ. Bacterial adhesion to surface hydrophilic and hydrophobic contact lenses. Biomaterials. 2001;22(24):3217-24.

30. Liesegang TJ. Contact lens-related microbial keratitis: part II: Pathophysiology. Cornea. 1997;16(3):265-73.

31. Tam C, Mun JJ, Evans DJ, Fleiszig SM. The impact of inoculation parameters on the pathogenesis of contact lens-related infectious keratitis. Invest Ophthalmol Vis Sci. 2010;51(6):3100-6.

32. Anwar H, Dasgupta MK, Costerton JW. Testing the susceptibility of bacteria in biofilms to antibacterial agents. Antimicrob Agents Chemother. 1990; 34(11):2043-6.

33. Cutruzzola F, Frankenberg-Dinkel N. Origin and impact of nitric oxide in Pseudomonas Aeruginosa biofilms. J Bacteriol. 2016;198(1):55-65.

34. Schlag S, Nerz C, Birkenstock TA, Altenberend F, Gotz F. Inhibition of staphylococcal biofilm formation by nitrite. J Bacteriol. 2007;189(21):7911-9.

35. Jenal U, Malone J. Mechanisms of cyclic-di-GMP signaling in bacteria. Annu Rev Genet. 2006:40:385-407.

36. Liu N, Xu Y, Hossain S, Huang N, Coursolle D, Gralnick JA, Boon EM. Nitric oxide regulation of cyclic di-GMP synthesis and hydrolysis in Shewanella woodyi. Biochemistry. 2012;51(10):2087-99.

37. Barraud N, Kardak BG, Yepuri NR, Howlin RP, Webb JS, Faust SN, Kjelleberg S, Rice SA, Kelso MJ. Cephalosporin-3'-diazeniumdiolates: targeted NO-donor prodrugs for dispersing bacterial biofilms. Angew Chem Int Ed Eng. 2012; 51(36):9057-60.

38. Friedman A, Blecher K, Sanchez D, Tuckman-Vernon C, Gialanella P, Friedman JM, Martinez LR, Nosanchuk JD. Susceptibility of gram-positive and -negative bacteria to novel nitric oxide-releasing nanoparticle technology. Virulence. 2011;2(3):217-21.

39. Jones ML, Ganopolsky JG, Labbe A, Wahl C, Prakash S. Antimicrobial properties of nitric oxide and its application in antimicrobial formulations and medical devices. Appl Microbiol Biotechnol. 2010;88(2):401-7.

40. Miller C, McMullin B, Ghaffari A, Stenzler A, Pick N, Roscoe D, Ghahary A, Road J, Av-Gay Y. Gaseous nitric oxide bactericidal activity retained during intermittent high-dose short duration exposure. Nitric Oxide. 2009;20(1):16-23.

41. Allan RN, Morgan S, Brito-Mutunayagam S, Skipp P, Feelisch M, Hayes SM, Hellier W, Clarke SC, Stoodley P, Burgess A, et al. Low concentrations of nitric oxide modulate Streptococcus Pneumoniae biofilm metabolism and antibiotic tolerance. Antimicrob Agents Chemother. 2016;60(4):2456-66.

42. Major TA, Panmanee W, Mortensen JE, Gray LD, Hoglen N, Hassett DJ. Sodium nitrite-mediated killing of the major cystic fibrosis pathogens Pseudomonas Aeruginosa, Staphylococcus Aureus, and Burkholderia cepacia under anaerobic planktonic and biofilm conditions. Antimicrob Agents Chemother. 2010:54(11):4671-7.

43. Jardeleza C, Foreman A, Baker L, Paramasivan S, Field J, Tan LW, Wormald PJ. The effects of nitric oxide on Staphylococcus Aureus biofilm growth and its implications in chronic rhinosinusitis. Int Forum Allergy Rhinol. 2011;1(6):438-44.

44. Okajima Y, Kobayakawa S, Tsuji A, Tochikubo T. Biofilm formation by Staphylococcus Epidermidis on intraocular lens material. Invest Ophthalmol Vis Sci. 2006;47(7):2971-5.

45. Baillif S, Casoli E, Marion K, Roques C, Pellon G, Hartmann DJ, Freney J, Burillon C, Kodjikian L. A novel in vitro model to study staphylococcal biofilm formation on intraocular lenses under hydrodynamic conditions. Invest Ophthalmol Vis Sci. 2006;47(8):3410-6.

46. YT W, Tam C, Zhu LS, Evans DJ, Fleiszig SM. Human tear fluid reduces Culturability of contact lens-associated Pseudomonas Aeruginosa biofilms but induces expression of the virulence-associated type III secretion system. Ocul Surf. 2017;15(1):88-96.

47. Bebarta VS, Brittain M, Chan A, Garrett N, Yoon D, Burney T, Mukai D, Babin M, Pilz RB, Mahon SB, et al. Sodium nitrite and sodium Thiosulfate are effective against acute cyanide poisoning when administered by intramuscular injection. Ann Emerg Med. 2017;69(6):718-25. e714

48. Ulici A, Jancik J, Lam TS, Reidt S, Calcaterra D, Cole JB. Clevidipine versus sodium nitroprusside in acute aortic dissection: a retrospective chart review. Am J Emerg Med. 2017;

\section{Submit your next manuscript to BioMed Central and we will help you at every step:}

- We accept pre-submission inquiries

- Our selector tool helps you to find the most relevant journal

- We provide round the clock customer support

- Convenient online submission

- Thorough peer review

- Inclusion in PubMed and all major indexing services

- Maximum visibility for your research

Submit your manuscript at www.biomedcentral.com/submit
C Biomed Central 